\title{
Genetic and nongenetic cellular resistance adaptation in marine invertebrates
}

\author{
CARl Schlieper \\ Institut für Meereskunde der Universität Kiel, Kiel
}

\begin{abstract}
KURZFASSUNG: Genetische und nichtgenetische zelluläre Resistenzadaptation bei marinen Evertebraten. Es ist ein allgemeinbiologisches Grundprinzip, daß jede tierische und pflanzliche Art in gewissem Maße an das besondere Klima ihres Lebensraumes angepaßt ist. Die hierbei wirksamen zellulären Adaptationen sind genetisch bestimmt und durch natürliche Variation und Selektion während der Ausbreitung des Lebens über die Erde entstanden. Sie sind auch die Grundlage für die Entwicklung besonderer organphysiologischer Anpassungen und der den ganzen Organismus umfassenden Adaptationen. Artspezifische Resistenzadaptationen können leicht an den Uberlebensraten und -zeiten einzelner Zellen oder Gewebestücke vieler mariner Evertebraten (Muscheln, Seesterne, Seerosen etc.) nach Änderung eines oder mehrerer Außenfaktoren -- wie beispielsweise Salzgehalt, hydrostatischer Druck, Temperatur etc. - gemessen werden. Die so erhaltenen zellphysiologischen Werte sind für die Charakterisierung der Arten ebenso wichtig wie ihre morphologischen Besonderheiten. Manche euryöke marine Evertebraten, die in einem breiteren Bereich abiotischer Außenbedingungen überleben, zeigen auch zelluläre umgebungsbedingte Resistenzänderungen beziehungsweise nichtgenetische Adaptationen (Akklimatisationen) innerhalb der Grenzen ihrer genetisch fixierten Reaktionsnorm. Nichtgenetische zelluläre Resistenzadaptationen können spezifisch und unspezifisch erfolgen. Bei spezifischer thermischer Adaptation verschieben sich beispielsweise die individuellen unteren und oberen Letaltemperaturen in der gleichen Richtung, das heißt Warmadaptation bedingt Erhöhung der Hitzeresistenz bei gleichzeitiger Verringerung der Kälteresistenz. Durch unspezifische Resistenzadaptation kann demgegenüber ein größerer Resistenzbereich (gegenüber Hitze, Kälte, Druck etc.) gleichzeitig nach mehreren Richtungen verbreitert oder verengert werden. Schockeffekte (kurzfristige Einwirkung subletaler Bedingungen) können auf diese Weise durch Stabilisierung der Protoplasmastrukturen und Funktionen (Härtung) eine breite unspezifische Resistenzerhöhung zur Folge haben. Während der Laichperioden, bei längeren Hungerzeiten und bei Anpassung euryhaliner Evertebraten an Brackwasser sind dagegen unspezifische Resistenzabnahmen auf Grund einer relativen Entstabilisierung der Protoplasmaeigenschaften (Enthärtung) zu beobachten.
\end{abstract}

\section{INTRODUCTION}

Ecological physiology deals with the relationships between the physiological capacities and abilities of the organisms and the biotic and abiotic qualities of their environment. In this connection I shall especially discuss the physiological adaptations of marine invertebrates to the abiotic, that is, the physico-chemical, external conditions of their biotopes. These adaptations can be studied at three different levels: (1) The physiological behaviour of whole animals under different external conditions can be 
investigated. (2) The physiological capacities and reactions of certain organs after changing or in relation to certain external factors can also be analysed. (3) Finally, the cellular adaptations of the organisms which are situated in the protoplasm can be investigated in relation to the special climate of their environment.

We know that life or survival of marine species under the quite different, partly extreme climates of their distribution areas (such as the tropics, polaric waters, estuaries, deep sea, etc.) is only possible by specific, especially metabolic adaptations at the three beforementioned different levels. Cell physiological adaptations are always the basis. They are the prerequisites for the development and the functioning of special organ physiological adaptations and of those adaptations. which comprise the whole organism. They are fixed genetically and originated from more simple cell qualities by genetic variation and natural selection during the colonization of the marine spaces.

If it is true that the first marine invertebrates appeared in the tropical coastal sea, then these species must have been largely stenoecous, warm-stenothermal, stenohaline and stenobath-barophob, similar to the present tropical litoral marine invertebrates. New, differently adapted cold-stenothermal, eurythermal, euryhaline, eurybath and stenobath-barophile species originated for the first time during their extension into the other marine areas.

Our first question now is: How can we measure the extent and the capacity of the different existing cell physiological adaptations? After a solution has been found to this problem, the second question follows: How are the basic mechanisms of these cell physiological adaptations constructed? Only after having succeeded in answering these two primary questions satisfactorily will we be able to comprehend the phylogenetic development of these ecological adaptations.

\section{CELLULAR OSMOTIC RESISTANCE}

At the "Institut für Meereskunde" at Kiel we started with an investigation of the genetic cellular osmotic resistances of marine invertebrates (especially bivalves, starfishes and sea anemones). It is possible to keep gill pieces of the poikilosmotic marine bivalves surviving for several days in pure sea water without difficulties. And it is easy to control the activity and the survival of each single piece by observing microscopically the continuance and the rate of the cilial movements. The principle of our measurements is to transfer small gill pieces or other ciliated epithelia of single individuals into a series of petri dishes filled with gradually diluted or concentrated sea water. After 24 hours the examination of the activity of the cilial beating will show exactly the extent of the osmotic resistance. If we agree to use the number " 3 " for normal cilial activity, the number " 2 " for a little diminished activity and the number " 1 " for a strongly reduced activity with 50 to 90 per cent of non-moving cilia, we can easily obtain by repeated experiments reproducible mean values.

Using this method we have investigated, among others, the species presented in Figure 1. Of these species, Spisula solida exhibits the lowest degree of osmotic resistance. This bivalve species is relatively stenohaline and occurs in depths of 10 to $50 \mathrm{~m}$ in the North Sea. It extends from the north of Norway and from Iceland southwards to 
the Mediterranean Sea and is absent in the brackish water of the Baltic Sea. Larger resistance ranges show that the more euryhaline species of the upper litoral, Cardium edule and Mytilus edulis, occur also in the Baltic Sea. With the aid of the same examination method, many other species of bivalyes were investigated by SCHLIEPER,

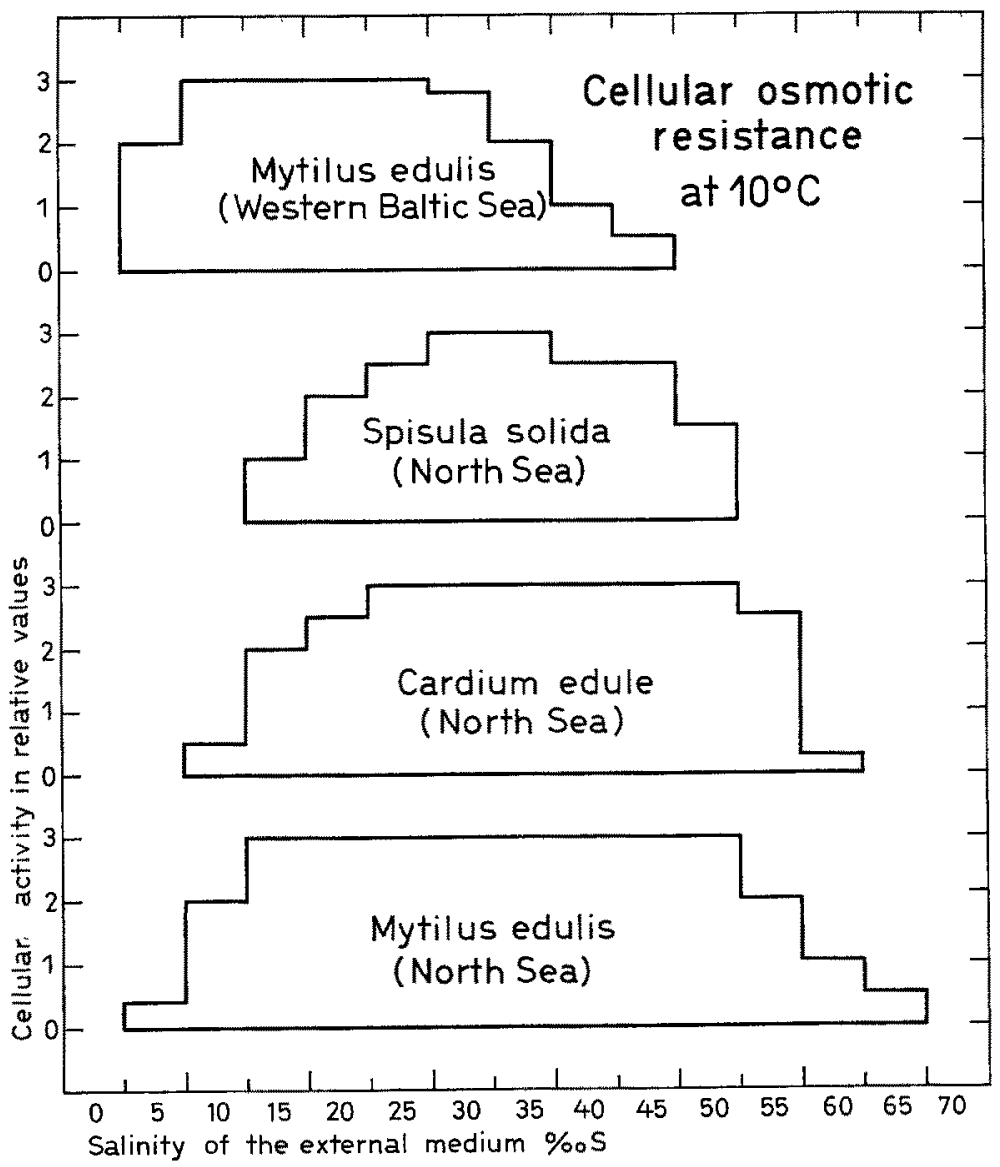

Fig. 1: Cellular osmotic resistances in three bivalve species. Experiments were performed with isolated gill pieces; mean values of ten single observations in each case. (After THEEDE 1965)

FLÜGel \& Rudolf (1960), Reshöft (1960), Vernberg, SChlieper \& SchNeIder (1962) and THEEDE (1965). In every case distinct correlations were found between the experimentally determined cellular dilution limits and the immigration of the same species into the brackish waters of estuaries.

Tropical species from the upper rocky litoral, which we recently investigated (SCHLIEPER, FLÜGEL \& THEEDE, in print), indicate a larger cellular concentration resistance, which explains the survival of these species in lagoons with more concentrated salt waters and highly situated splash water pools in arid coastal areas. 
It is always necessary, however, to determine the cellular osmotic resistance at the optimum temperature of every species. Only then will the surviving isolated tissue pieces display their maximum osmotic resistance. On the other hand, if a warm water species is investigated at lower temperatures or a cold water species at higher temperatures, smaller cellular osmotic resistance extents will be obtained (see also Fig. 2).

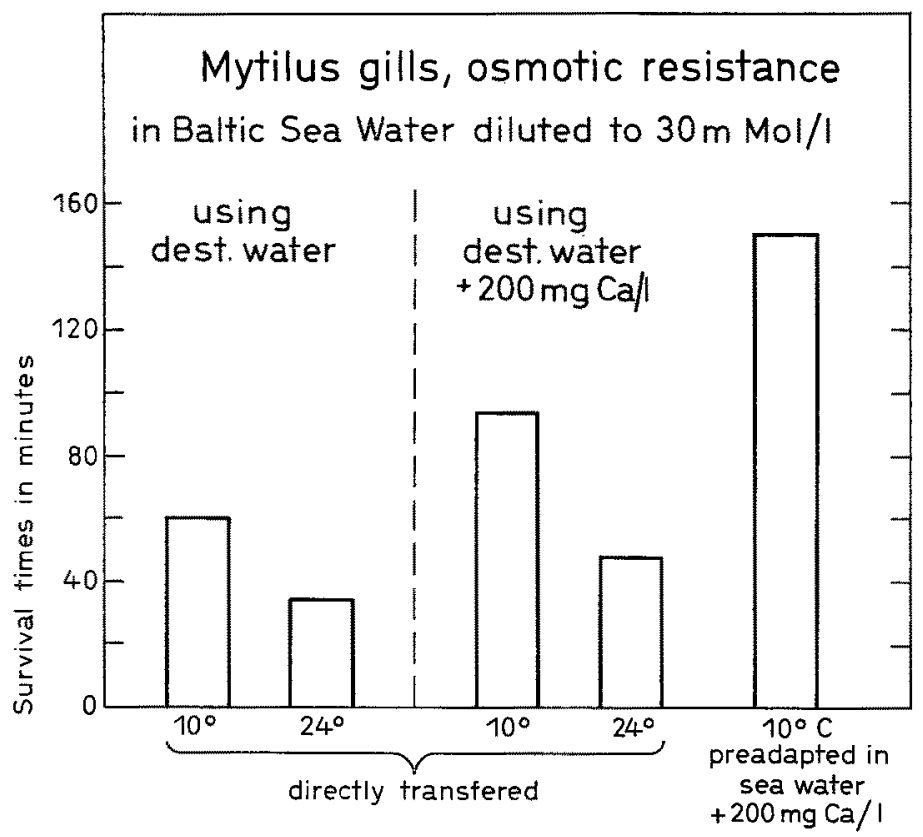

Fig. 2: Cellular osmotic resistance of Mytilus edulis in diluted sea water at different temperatures and in diluted sea water with increased $\mathrm{CaCl}_{2}$-contents. Isolated gill pieces of Mytilus edulis from the Western Baltic Sea (15\% $\mathrm{S}$ and $236 \mathrm{mMol} / \mathrm{l})$.

(After SCHLIEPER \& Kowalski 1956)

Nongenetic cellular osmotic adaptations will be observed if we compare different populations of euryhaline species from sea and brackish water areas, for example, Mytilus edulis from the North Sea $(32 \% \mathrm{~S})$ and from the Western Baltic Sea $(15 \%$ S) (Fig. 1). Such individual adaptation differences disappear, however, almost completely after prolonged cross adaptation. Yet it seems possible that the special adaptation of the Mytilus population living in brackish waters of very low salinity $(6 \% 0 \mathrm{~S})$ along the Finnish coast is not completely environmentally induced, but because of the long distance from the open sea and the prolonged isolation - may be also partly genetically determined. This question can, however, only be clarified by long-period adaptation and culture experiments.

Not only the temperature but also the calcium contents of the external medium influence the dilution resistance. This phenomenon, already observed in earlier experiments with intact brackish water inhabitants, applies also to the cellular osmotic resistance (Fig. 2). The survival time of isolated gill pieces of Mytilus in brackish water 
of very low salinity is therefore distinctly higher if the calcium concentration of the external medium is increased.

The analysis of this observation has shown that the really decisive factor in the increase of osmotic resistance is the internal calcium level of the cells themselves (SchliEper \& Kowalski 1956). It seems to me that the mechanism of the calcium effect is not so much the influence of calcium ions on the permeability of the cell membranes but is based more on a stabilization of the gel structure and protein complexes in the protoplasm.

\section{CELLULAR PRESSURE RESISTANCE}

In our investigation of the cellular pressure resistance, we are working with cylindrical bombs of stainless steel with capacities of 400 to $800 \mathrm{ml}$, such as those used by ZoBeLl (1958) in his experiments with deep sea bacteria. The high hydrostatic pressure is, in addition to darkness and coldness, a main characteristic of the deep sea.

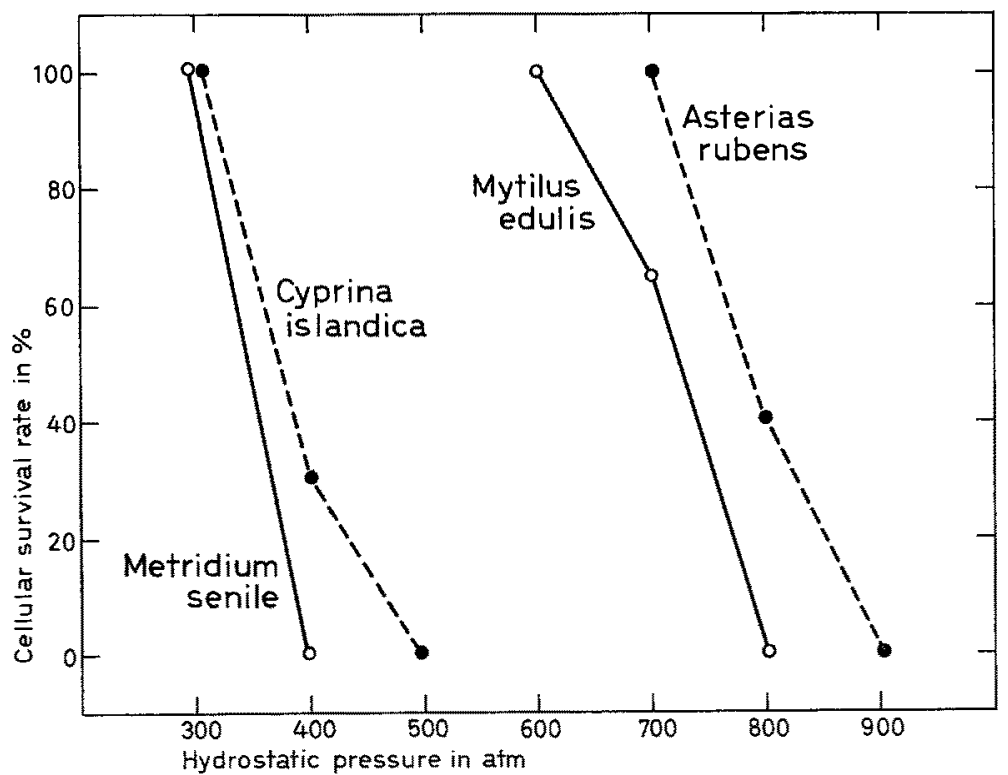

Fig. 3: Cellular pressure resistances of 4 litoral bottom invertebrates from the North Sea. Each value is based on isolated ciliated epithelia from 10 specimens. Sea water of $30 \%$ S and $10^{\circ} \mathrm{C}$. (After Ponat, unpublished observations)

The pressure increases about $1 \mathrm{~atm}\left(1 \mathrm{kp}\right.$ per $\left.\mathrm{cm}^{2}\right)$ for every $10 \mathrm{~m}$ and amounts to 200 to $600 \mathrm{~atm}$ in the abyssal deep sea of 2 to $6 \mathrm{~km}$ depth. It increases to 1000 to $1100 \mathrm{~atm}$ in the hadal deep sea trenches of 10 to $11 \mathrm{~km}$ depth. Only a relatively small number of species is able to survive at such high pressures.

The greater part of those species occuring in the coastal shallow waters is steno- 
bath-barophob and succumbs quickly if the pressure is experimentally raised to 300 to $400 \mathrm{~atm}$ (Еввеске 1944). Only relatively few species have the ability to live at larger ranges of depth and are therefore called eurybath.

To obtain comparable values of cellular pressure resistances, we kept gill pieces of marine bivalves or other ciliated epithelia of marine invertebrates for certain periods at different constant pressures. One tissue piece was always used per animal. The value for the amount of pressure resistance was then the percentage of surviving tissue pieces (Fig. 3). The results so obtained proved clearly that the tissues of some species are distinctly more resistant against increasing pressures than those of other species from

\section{a)}

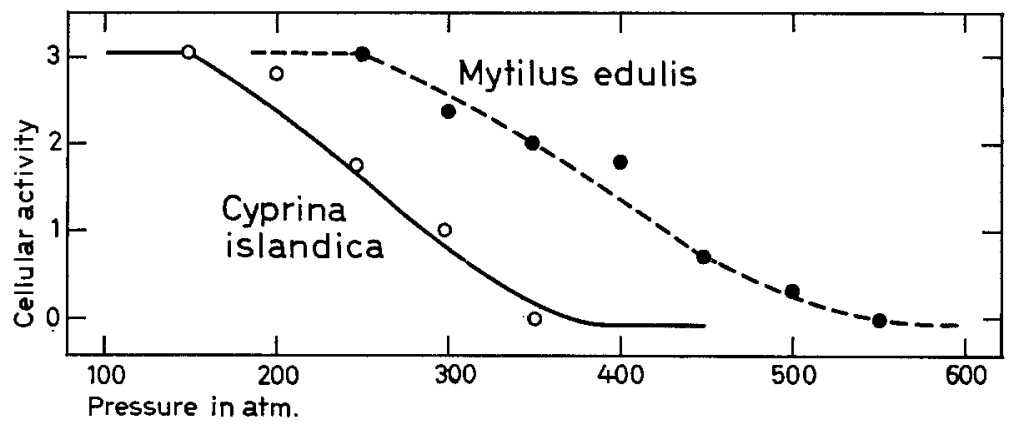

b)

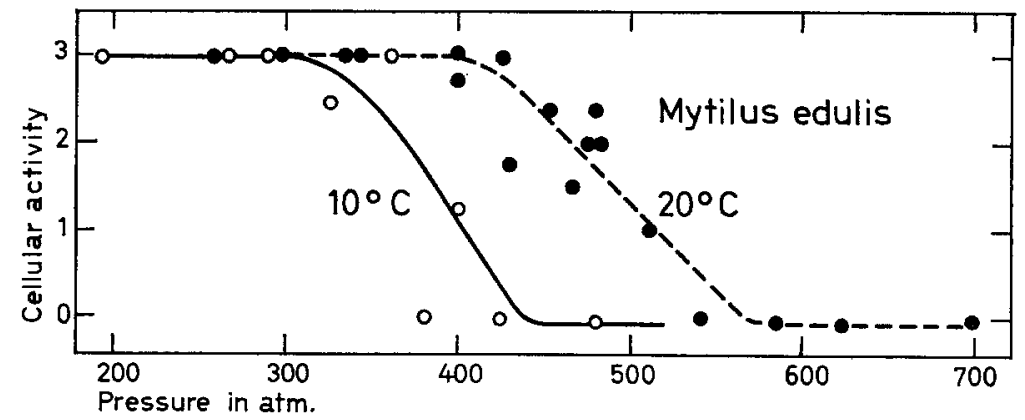

Fig. 4: Cellular pressure resistances of bivalves. Experiments with isolated gill pieces; (a) 2 bivalve species. (After SCHLIEPER \& PONAT, from SchlIEPER 1963), (b) Mytilus edulis investigated at 2 different temperatures. (After SCHLIEPER 1963)

the same biotop. Normally species, genera or families with greater vertical distribution have higher cellular pressure resistances. Also euryoecous species are often more resistant in this connection, even though they do not use this special capacity under normal conditions.

In other experimental series we kept tissue pieces at different pressures from 6 to 24 hours and afterwards quantitatively estimated the cellular activity under normal pressure (using the same system of evaluation as in the investigation of the osmotic 
resistance). By this procedure we obtained easily reproducible pressure activity curves, which permitted a more detailed analysis of pressure effects. In investigating, for example, the cellular pressure resistance of Mytilus edulis at $10^{\circ}$ and $20^{\circ} \mathrm{C}$, one always finds a greater pressure resistance at higher temperatures (Fig. 4). This result is not surprising if one considers that solid protoplasmatic gels are passing under increasing pressure more and more into the less viscous sol form (MarsLAND 1958). At increasing temperature the sol-gel relation of the protoplasm contrarily shifts in the direction of gel formation. It needs therefore a greater pressure at higher temperatures to diminish the plasmatic viscosity and to produce the same cell damages. From this observation it may be concluded that survival in the deep sea at its existing pressure would be easier if the water temperature would be not so low in that biotope. But it seems to me that the process of thermal adaptation may also have some influence in the development of a sufficient cellular pressure resistance at the low temperature of the deep sea.

\section{Table 1}

Isolated gill tissue of the clam Mytilus editis (Baltic Sea specimens from $15 \%$ S). Relative degree of pressure resistance in relation to preadaptation temperatures and experimental temperatures. Gill pieces of the same specimens were investigated at two temperatures. Each value represents the mean of 10 single observations; standard deviations are given for each mean value. (Unpublished observations of PONAT)

\begin{tabular}{|ccc|}
\hline & Activity after 24 hours at 400 atm at two different \\
Adaptation & experimental temperatures \\
temperature & $5^{\circ} \mathrm{C}$ & $15^{\circ} \mathrm{C}$ \\
\hline $5^{\circ} \mathrm{C}$ & $1,7 \pm 0,5$ & $2,4 \pm 0,5$ \\
$10^{\circ} \mathrm{C}$ & $0,9 \pm 0,7$ & $2,5 \pm 0,5$ \\
$15^{\circ} \mathrm{C}$ & $0,6 \pm 0,5$ & $2,5 \pm 0,5$ \\
\hline
\end{tabular}

PONAT proved in my laboratory that at least a part of the diminishing influence of cold to pressure resistance may be compensated for by cold adaptation. In this way, the relatively high cellular pressure resistance of warm adapted specimens of Mytilus breaks down in cold water but recovers considerably after prolonged cold adaptation (Table 1).

One may therefore assume that the level and the constancy of plasmatic viscosity, that is, the stability of protoplasmatic structure, is most important for the degree of cellular pressure resistance. In agreement with this assumption is the fact that the pressure resistance of gill pieces from Mytilus adapted to brackish water is much lower than of those specimens living in normal sea water. In every case the softer tissues of brackish water mussels, which have a higher water content, also have a smaller pressure resistance. In connection with this fact we must remember the previous observation that the stability of the protoplasmatic colloids and the cellular osmotic tesistance can be increased by raising the calcium contents of the tissues. We have therefore also investigated the influence of a preadaptation to $\mathrm{Ca}$-enriched sea water on the pressure resistance. Our relevant experiments with isolated tissues are not yet finished but appear to be confirmative; I can further report successful experiments with small hermit crabs (Eupagurus zebra). These animals survive during one hour at $200 \mathrm{~atm}$, 
but die without exception at $250 \mathrm{~atm}$. We adapted a number of the crabs for at least three days to sea water with double calcium contents. All of the so treated specimens survived without damage at 250 and 275 atm (Schlieper, Flügel \& Theede, unpublished observations).

\section{CELLULAR COLD AND FREEZING RESISTANCE}

I am now going to discuss thermal cellular resistances. I do not need to stress the important role of temperature and temperature adaptations in the life of marine invertebrates. We can differentiate between cold, frost and heat resistance adaptations. The cellular cold resistance can be measured by survival times at constant low temperatures or by determining the cellular activity at slowly decreasing water temperatures.

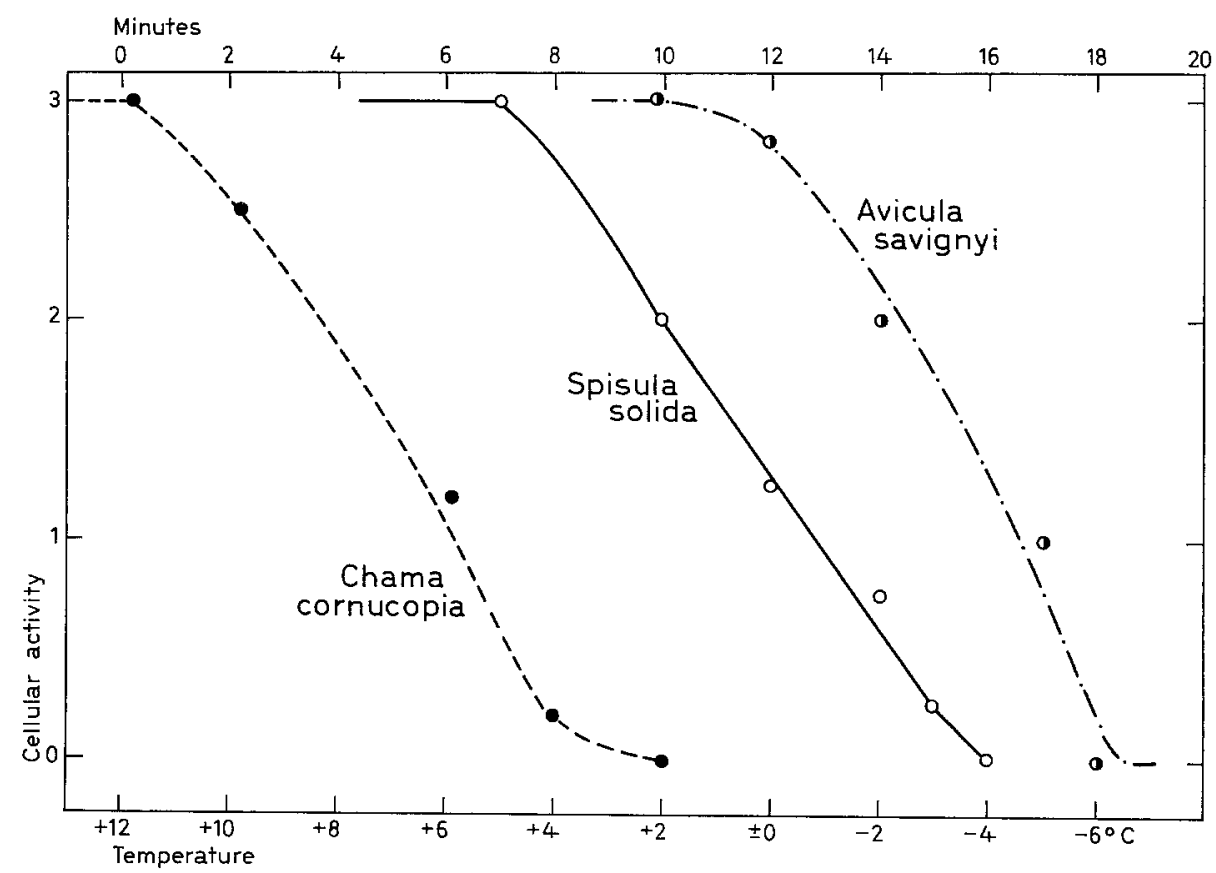

Fig. 5: Cellular cold resistances of tropical and temperate bivalves. Experiments with isolated gill pieces at slowly decreasing temperatures. (After SCHLIEPER, FLÜGEL \& THEEDE, unpublished observations)

We can undercool pure sea water without freezing until $-5^{\circ}$ or $-6^{\circ} \mathrm{C}$. If we observe the cilial beating of gill pieces from tropical litoral bivalves at slowly decreasing water temperature, we find that the cilial movements decrease already at $10^{\circ}$ or $8^{\circ} \mathrm{C}$ or even earlier and come to a complete standstill before the temperature reaches zero (Fig. 5). In contrast, the tissues of temperate and polar litoral species are active and unharmed at $0^{\circ} \mathrm{C}$. The cells of tropical and other species from deeper cooler water layers of the ocean also exhibit a similar high cold resistance. Because of the more effective cooling 
of the sea water in the tidal region of the temperate zone during winter time, the species of the epifauna of this area are more cold and frost resistant than the species from the deeper sea bottom.

THEEDE (1965) was the first one to compare measurements on the cellular freezing resistance of marine invertebrates. He froze small tissue pieces for different periods of time at $-10^{\circ} \mathrm{C}$ and observed their activity and survival ability at room temperature after a sufficient time of recovery. By this means THEEDE proved that the species which suffered particularly during the severe winters $1928 / 29$ and $1962 / 63$ were also measurably less resistant in laboratory experiments (Fig. 6). The investigated species from the

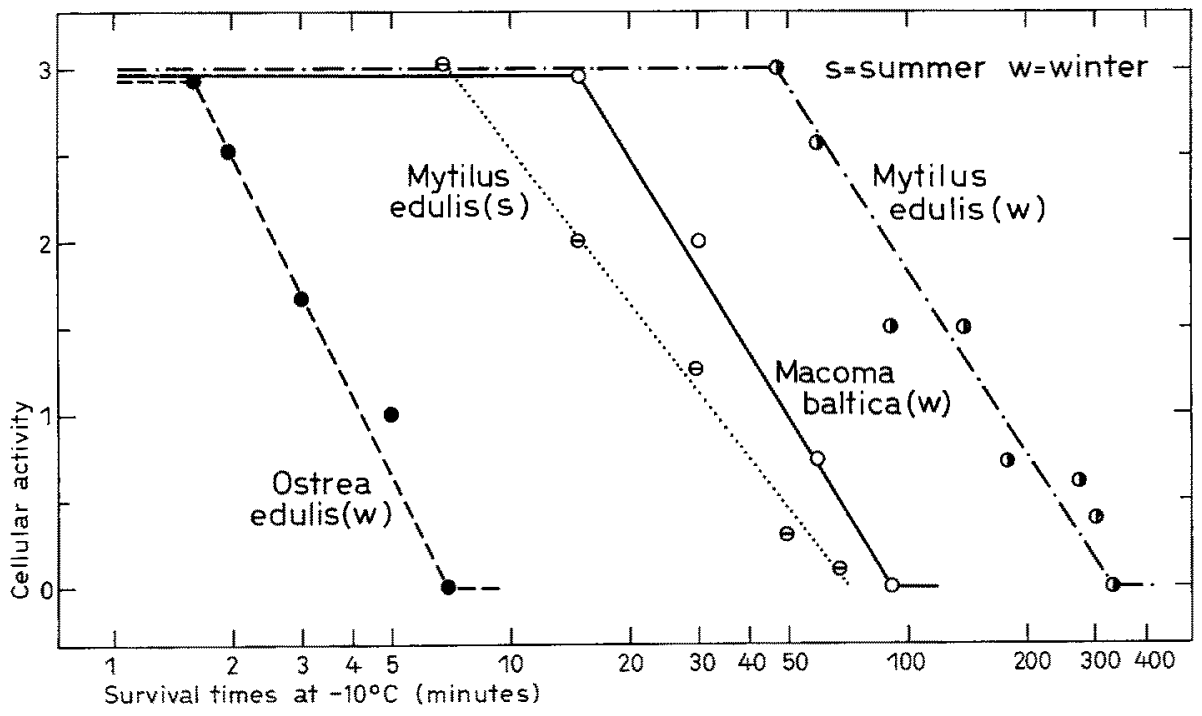

Fig. 6: Cellular freezing resistances of 3 bivalve species from the North Sea (30\% S).

(After THEEDE 1965)

North Sea, arranged in sequence according to their decreasing freezing resistance, were: Mytilus edulis, Cardium edule, Macoma baltica, Modiolus modiolus (Ostrea edulis) and Spisula solida. The tissues of Mytilus from the tidal zone survived freezing at $-10^{\circ} \mathrm{C}$ for several hours, whereas Spisula from deeper sandy bottoms showed irreversible cell damages after only 4 minutes.

The relatively high freezing resistance of the more euryoecous temperate shallow water species is, however, not an absolutely constant value. It is always much higher in winter than in summer (compare Fig. 6). Furthermore, it is influenced by the salinity of the sea water. Therefore the specimens of Mytilus from the brackish water of the western Baltic Sea $(15 \% 0 \mathrm{~S})$ have a much lower cellular freezing resistance than those from the more saline sea water of the North Sea $(32 \% \mathrm{~S})$. The cellular freezing resistance measurably increases to the same extent after addition of organic substances, such as sucrose, glucose and glycerol, to the sea water (THEEDE 1965). The effective mechanism of these "anti-freezers" is, in my opinion, mainly osmotical by retardation of intracellular ice formation and by reduction of the sudden raising of intracellular 
electrolyte concentration during the freezing. There may possibly also be an influence on the shape of the ice crystals. Our experimental investigations on the influence of nongenetic temperature adaptations to the cellular cold and freezing resistance of marine eurythermal invertebrates are not yet finished. But the results already show distinct nongenetic adaptations of the kind. PRECHT \& Christopherson (1965) succeeded too in proving a nongenetic cellular cold adaptation with tentacles of freshwater snails. I am therefore convinced that environmentally induced cold and freezing adaptations also play a certain role in the life of eurythermal litoral marine invertebrates of the temperate zones.

\section{CELLULAR HEAT RESISTANCE}

The cellular heat resistance of marine invertebrates is certainly very important as a species specific characteristic. But too many investigators have also neglected to investigate cellular resistance adaptations in relation to other factors. Only by exploring the complete cellular behaviour relative to all possible abiotic factors and factor combinations, will we obtain a full picture of the cellular adaptation possibilities.

We can measure cellular heat resistance limits at slowly increasing temperatures and at constant lethal temperatures (Fig. 7 and 8 ). The values obtained in this way can be well reproduced under identical conditions. They are important for the comprehension of the distribution possibilities of the different species, as well as of the north-south extension in shallow and surface waters and of the vertical species ranges. In all stenothermal species of the tropical and temperate zones, the genetically induced cellular heat resistances decrease with increasing habitat depth. If there is one species in a certain biotope with extraordinary resistance values, then it is generally a species which normally occurs in a quite different area and has only recently immigrated to that place and not yet completely adapted to the local external conditions. As an example, I would like to mention that ReshöfT (1961) found in the Kiel Canal a bivalve species which was extraordinarily heat resistant for this area. The species was Congeria cochleata, which normally lives in the warmer coastal waters of South West Africa.

The cellular heat resistance of marine invertebrates is also influenced by the salinity and the calcium concentration of the sea water. Therefore, the cellular heat resistance of the Mytilus populations living in the brackish waters of the Western Baltic Sea is considerably less in comparison with the capacities of the populations from normal sea water. It is also easily possible to increase the cellular heat resistance of brackish water mussels by raising the salinity or by raising only the concentration of calcium ions in the external medium (Fig. 9). Most essential in the last case is the level of the calcium concentration in the cells themselves.

We remember in this connection that the resistance against dilution of the sea water and against high pressure is also measurably increased by adding calcium ions to the external medium. This phenomenon of nonspecific resistance increase will have to be discussed more extensively at a later occasion.

The regularly occuring heat resistance losses during the spawning periods, such as in Mytilus edulis (DrEgorsKayA 1963), which I would like to consider as effects of 


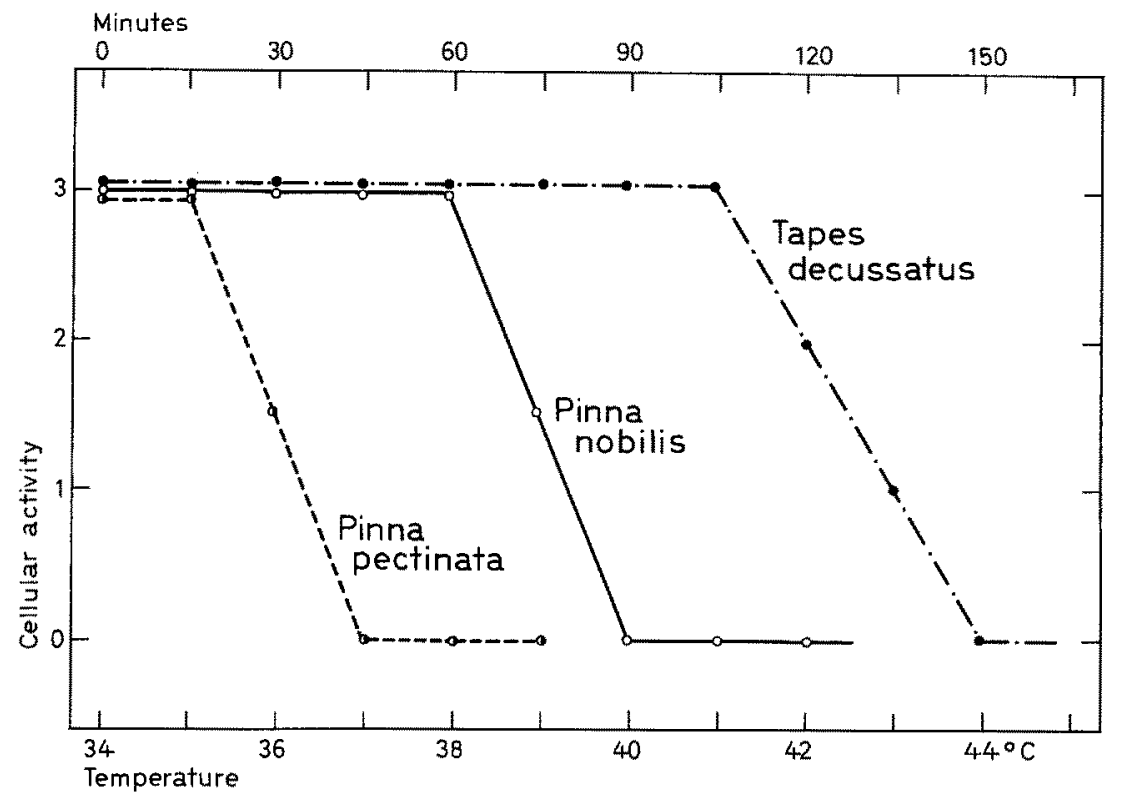

Fig. 7: Cellular heat resistances of 3 bivalve species from the French Mediterranean Coast at slowly increasing temperatures. Tapes from the upper litoral, Pinna nobilis from 10 to $15 \mathrm{~m}$ depth, $P$. pectinata from $100 \mathrm{~m}$ depth. (After SCHLIEPER, Fi j̇gEL \& Rudolf 1960)

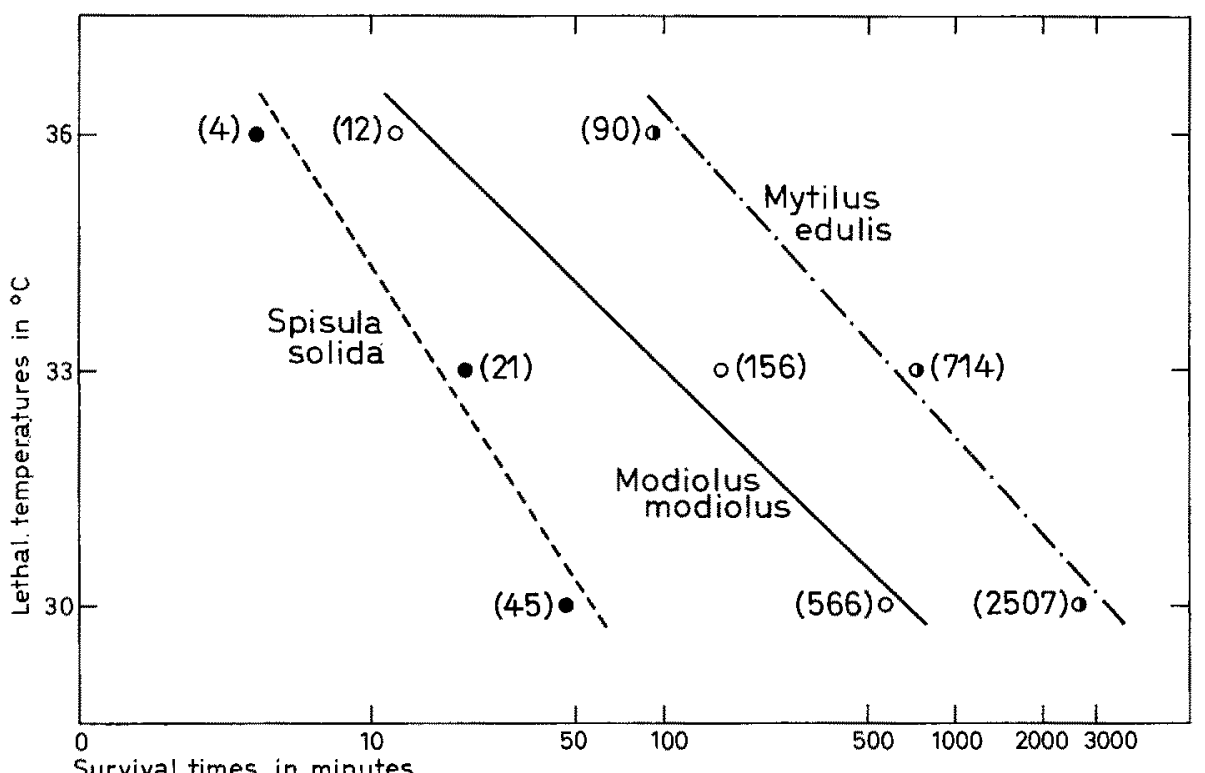

Fig. 8: Cellular heat resistances of 3 bivalve species from different depths of the North Sea at constant lethal temperatures. (After RESHÖFT 1961) 


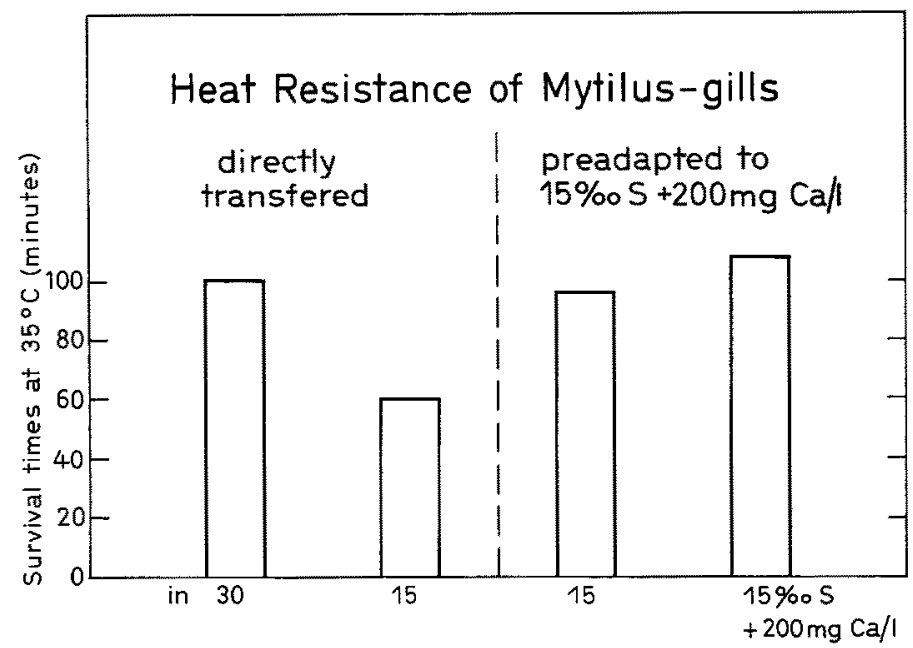

Fig. 9: Cellular heat resistance of Mytilus edulis in sea water of 30 and $15 \% \mathrm{~S}$ and in sea water of $15 \% \mathrm{~S}$ with increased $\mathrm{CaCl}_{2}$-contents. (After Schlreper \& Kowalski 1956)

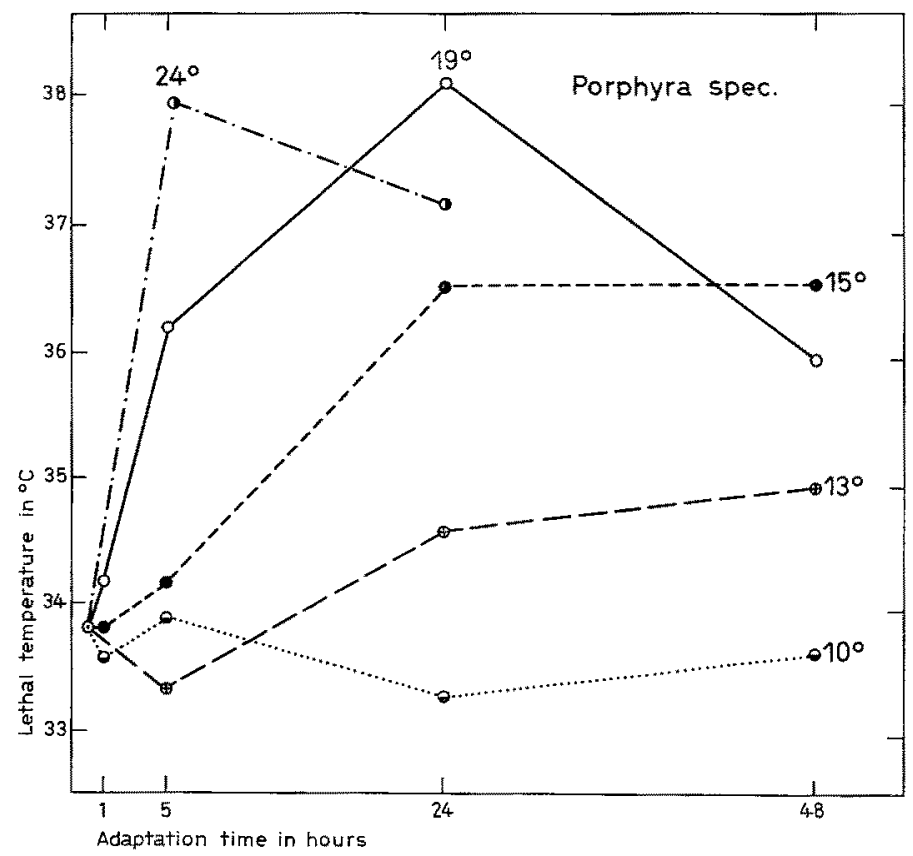

Fig. 10: Influence of warm adaptation on the cellular upper lethal temperature limit of a marine red alga (Porphyra sp.). (After FeLDMAN \& LuTova 1963)

nongenetic endogenic resistance reductions, must not be confused with the environmentally induced cellular resistance changes.

A good example of environmentally induced heat adaptations is shown by the investigations of FELDMANN \& LuTova (1963) on the marine alga Porphyra sp. 


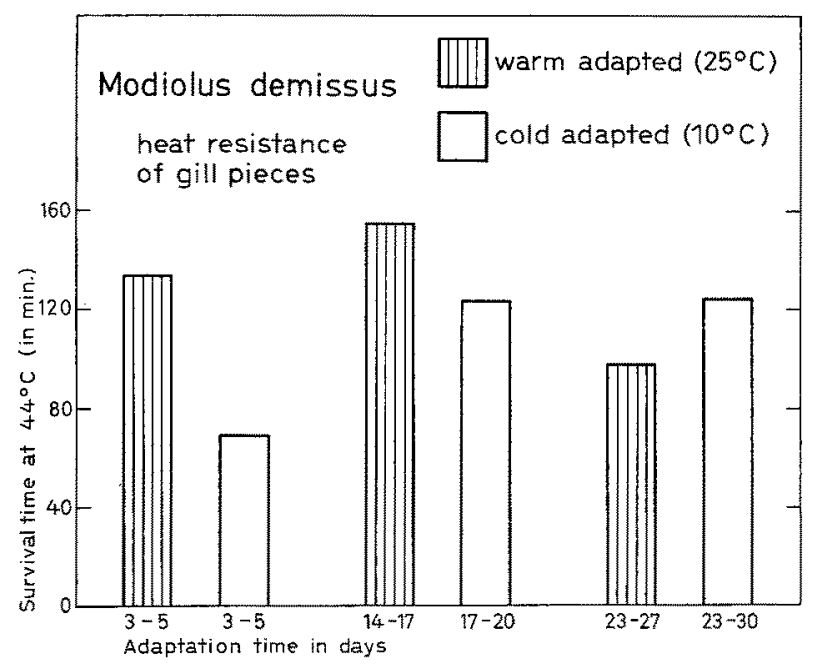

Fig. 11: Influence of adaptation time on the cellular heat resistance of a eurythermal bivalve species (Modiolus demissus) maintained under warm and cold conditions respectively. (After Vernberg, SCHLIEPER \& SCHNEIDER 1963)

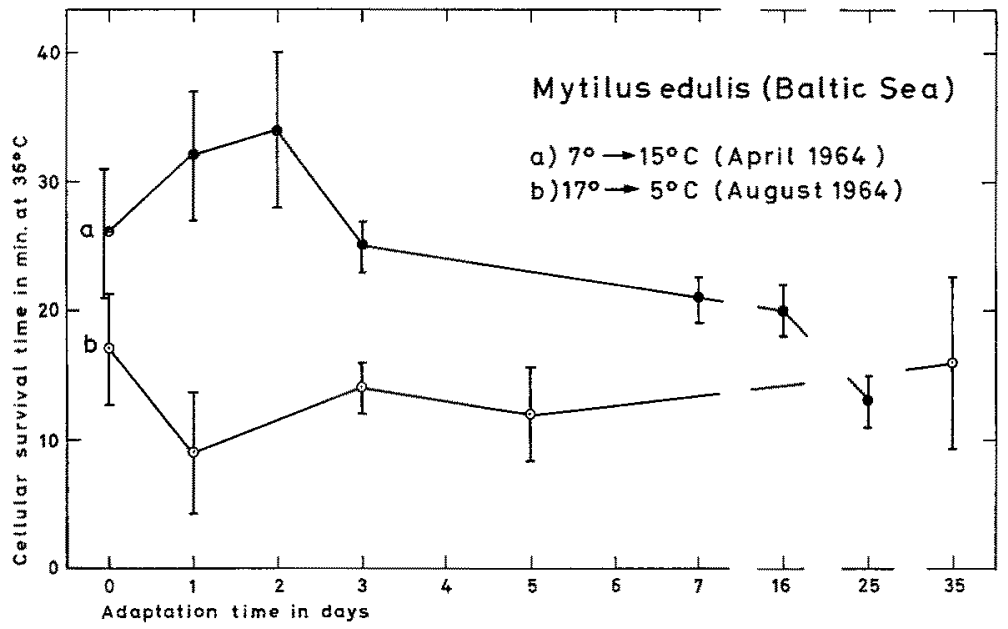

Fig. 12: Changes of cellular heat resistance in Mytilus edulis during adaptation to heat and cold. Mean values with standard deviations obtained from 10 single determinations. (After FRIEDRICH, unpublished results)

(Fig. 10). After transfer of the alga from $10^{\circ}$ into $15^{\circ}$ to $30^{\circ} \mathrm{C}$, the cellular heat resistance increases considerably within a few hours. Similar, very quickly induced cellular resistance changes may also be observed at the temperature adaptation of whole euryoecous marine invertebrates. Thus, for example, the cellular heat resistance of single tentacle pieces of Metridium senile increases significantly within 24 hours after the transfer of whole sea anemones from $5^{\circ}$ to $15^{\circ} \mathrm{C}$ (SCHLIEPER \& JäcKEL, unpublished observations). In other marine invertebrates the individual adaptation maximum 
determined by the increasing of the cellular heat resistance is attained after two to three days. During a prolonged warm adaptation of unfed marine invertebrates, the cellular heat resistance may later on decrease again (Fig. 11). That means - in my opinion - that the cellular heat resistance of starving specimens kept in warm sea water for longer periods will decrease by a reduction in nonspecific resistance. But a quite different type of thermal resistance adaptation might also be involved. Some eurythermal species are evidently able to adapt their cellular resistance normally over a period of some days after a sudden change of the temperature. Then, however, this (sensible) heat adaptation may disappear. In other words, it follows a regulatory

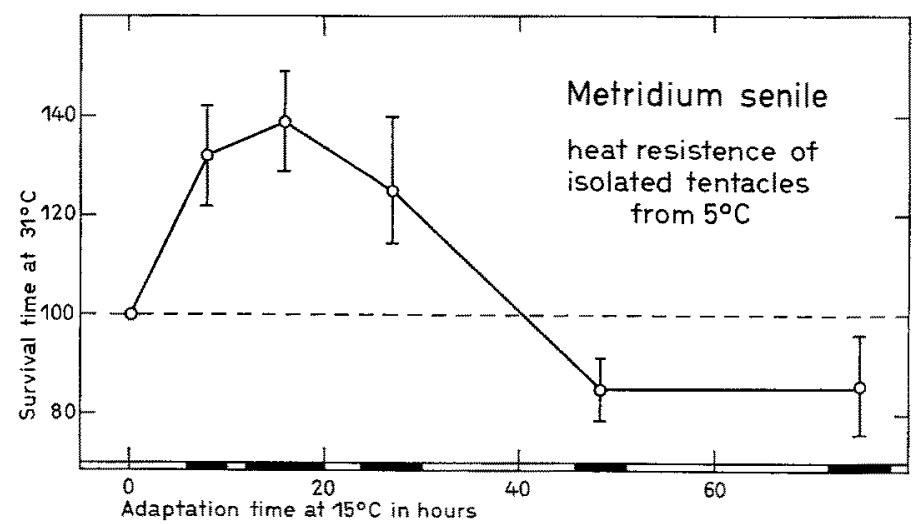

Fig. 13: Influence of adaptation time (at $15^{\circ} \mathrm{C}$ ) on the heat resistance of isolated tentacle pieces from the sea anemone Metridium senile, previously adapted to $5^{\circ} \mathrm{C}$. (After SCHLIEPER $\&$ JäCKEL, unpublished observations)

process if the temperature has remained within the well tolerable limits of the biotope temperatures of the population. At last, the cellular resistance of the investigated individuals again reaches the "normal medium resistance level" of the species, in spite of the different experimental temperature (Fig. 12).

In our laboratory we have recently experimented specifically on short time nongenetic resistance adaptations with tissue pieces of marine invertebrates. We started, for example, with cold adapted individuals of the sea anemone Metridium senile. We then transferred single tentacle pieces of the so pre-adapted animals into sea water having a $10^{\circ} \mathrm{C}$ higher temperature. The continually measured cellular heat resistance increased during the following 20 hours (due to specific warm adaptation). Afterwards it decreased slowly because of the beginning and growing disintegration of the isolated tissue pieces (due to nonspecific resistance reduction). After 40 hours the degree of resistance again reached the orginal level of the cold adapted animals (Fig. 13).

It is possible to obtain faster measurable resistance increases when we raise the external temperature for a short time to lethal ranges (heat shock experiments). This means that the process of cellular resistance adaptation starts immediately after the temperature change. Such fast resistance increases may also be important in free nature, if, for example, marine invertebrates have been trapped at low tide in small pools in which the temperature rises quickly by growing sun radiation. 
In order to comprehend the mechanism of heat shock effects, it is probably important that the oxygen consumption of isolated tissues diminishes after the shock, whereas the heat resistance increases (Fig. 14). Because the number of our experimental series is still small, I do not dare to maintain that (nonspecific) resistance increases are generally connected with a reduction of the metabolic intensity of tissues. But some facts

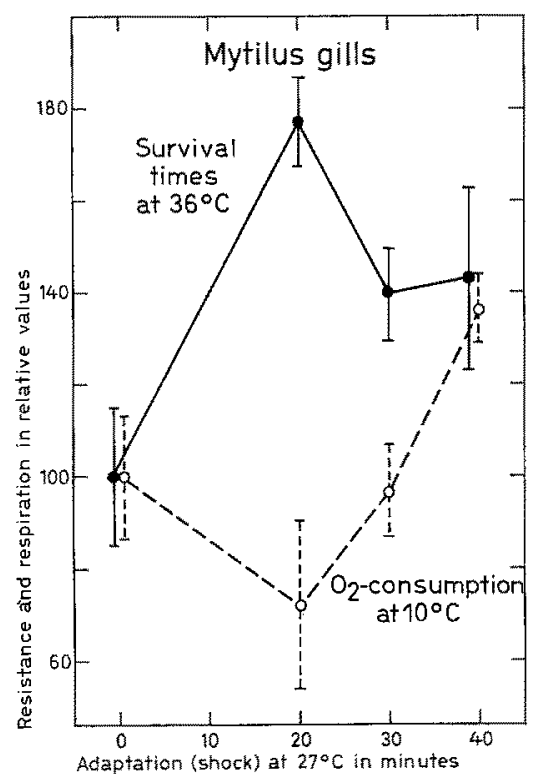

Fig. 14: Influence of heat shock time (at $27^{\circ} \mathrm{C}$ ) on the heat resistance and oxygen consumption of isolated gill pieces from mussels (Mytilus edulis) previously adapted to $10^{\circ} \mathrm{C}$.

(After Friedrich, unpublished results)

indicate that such correlations may be essential in resistance adaptations. Thus, for example, we could prove that the isolated gill pieces of Mytilus become considerably more heat resistant after being transferred for a short time into oxygen deprived water.

We could furthermore observe that quite different stress or shock effects may be connected with nonspecific resistance increases against heat, cold and pressure. Thus, for example, cold shocks (dipping of isolated gill tissue of Mytilus in undercooled sea water of $-5^{\circ} \mathrm{C}$ for only one or two minutes) generates significant increases of cellular heat resistance (FRIEDRICH, unpublished observations).

\section{CONCLUSIONS}

The reported results lead us to distinguish - in terms of a working hypothesis concerned with the whole range of the investigated nongenetic cellular resistance adaptations - at least two categories:

(1) Specific resistance adaptations. They may also be called (sen- 
sible) acclimatizations. To this category should belong, for example, the increase of heat resistance together with a simultaneous decrease of cold resistance during individual warm adaptation. In this case, the upper and lower cellular temperature limits shift in the same direction.

(2) Nonspecific resistance adaptations. They may be understood according to the kind of resistance change (increase or decrease) as a stabilization of protoplasmatic structures and functions (hardening) or a destabilization (dehardening). To this category would belong shock effects through which a broad resistance increase (extension of the total resistance range) is induced against quite different stresses (heat, cold, high pressure, etc.). Nonspecific resistance decreases occuring, for example, during spawning periods, during prolonged starvation or in brackish waters, should likewise belong to this category.

It seems still necessary to discuss whether or not the genetic resistance adaptations referred to above might also be included in this system.

With these considerations I would like to conclude my review of our investigations on ecological cell physiology of some lower marine invertebrates.

In the future we hope to obtain further results (1) by continuing our reported adaptation and shock experiments with surviving tissues, (2) by also investigating other cellular resistance adaptations (for example, in regard to oxygen lack, $\mathrm{H}_{2} \mathrm{~S}$, radiation damages, etc.), (3) by making comparative biochemical and biophysical analyses of the mechanisms of specific and nonspecific adaptations. Finally, an attempt must be made to elaborate a generally conclusive system of cellular resistance adaptations with reference and utilization of all the valuable existing investigations on this object (Merman 1956; Levitt 1958; Prosser 1958; Kinne 1963, 1964; Vernberg, Schlieper \& Schneider 1963; Alexandrov 1964; Barbashova 1964; Precht 1964; Ushakov 1964 ; etc.). It also seems necessary to me that a generally usable definition of the term "adaptation" has to be developed in this connection. In this paper "adaptation" has only been conceived of as a process which establishes or reestablishes an equilibrium between a living being and its environment after it has been disturbed by an alteration of one or several external abiotic factors.

\section{SUMMARY}

1. A general biological principle exists stating that every species is adapted in some degree to the special climate of its environment. By that means the life and respectively the survival are secured at the total scale of physico-chemical conditions which may normally occur in the particular distribution area. The thereby acting cellular adaptations are genetically determined and originated by natural variation and selection during the extension of life over the globe. They are also the basis for the development and the function of special organ physiological adaptions and for those adaptations which comprise the whole organism.

2. Species specific resistance adaptations can be measured by the survival rates or times of isolated cells or tissue pieces after altering one or several environmental factors, such as salinity, hydrostatic pressure, temperature, etc. This is exemplified in 
the review by many experimental observations on lower marine invertebrates. The physiological values obtained are, on the whole, as important for the characterization of the species and their distribution capacities as are their morphological pecularities. Furthermore, these experimental values represent a first step to an analy tical marine zoogeography at the cellular level.

3. Euryoecous species (bivalves, starfishes, sea anemones, etc.) which survive at a larger scale of abiotic conditions show also various cellular environmentally induced resistance changes and nongenetic adaptations (acclimatizations) between the limits of their broader genetic reaction extent. Nongenetic and genetic cellular adaptations probably function by means of equal mechanisms.

4. One can differentiate between cellular nongenetic resistance adaptations which are specific and nonspecific. In specific thermal resistance adaptations, for example, the individual lower and upper temperature limits shift in the same direction, which means that warm adaptation produces an increasing heat resistance while the cold resistance of the tissues decreases at the same time. By means of nonspecific resistance adaptations, the total cellular resistance extent (against heat, cold, frost, pressure, etc.) may be enlarged or diminished in several directions. Shock effects (short time sublethal stresses) may cause an immediate broad nonspecific resistance increase by stabilization of the structure and functions of protoplasm (hardening). Euryoecous marine invertebrates show also nonspecific resistance reductions by relative destabilization of the protoplasmatic qualities (dehardening), for example, during prolonged starvation, during spawning periods and after adaptation to brackish waters.

\section{ACKNOWLEDGEMENTS}

The investigations of Flügel, Jäckel, Kowalski, Friedrich, Ponat, Reshöft, SchliePER and THEEDE, mentioned in this review, were aided by grants from the Deutsche Forschungsgemeinschaft to the author.

Some of my own experiments were carried out in the laboratory of Professor T. H. Bullock at the University of California, Los Angeles. It is with great pleasure that I acknowledge this support and Dr. BurLock's interest in my studies. I also wish to thank my colleagues Professor O. Krnne (Hamburg) and Professor H. PRECHT (Kiel) for helpful discussions and Miss F. W. Crouse (Hamburg) for reading and improving my English manuscript.

\section{LITERATURE CITED}

AleXandrov, V. Y., 1964. Cytophysiological and cytoecological investigations of resistance of plant cells toward the action of high and low temperature. Q. Rev. Biol. 39, 35-77.

Barbashova, Z. I., 1964. Cellular level of adaptation. In: Handbook of physiology. Sect. 4. Adaptation to the environment. Am. Physiol. Soc., Washington, 37-54.

ERBECKE, U., 1944. Lebensvorgänge unter Einwirkung hoher Drucke. Ergebn. Pbysiol. 45, 34-183.

DregolskayA, I. N., 1963. Heat resistance of ciliated epithelium of Mytilus galloprovincialis L. from the Black Sea. In: Problems of cytoecology of animals. Academy of Sciences. of the USSR. Institute of Cytology. Collected articles. No. 6, 43-50 (in Russian). 
Faldmann, N. L. \& Lutova, M. I., 1963. Variations de la thermostabilité des algues en fonction des changements de la température du milieu. Cah. Biol. mar, 4, 435-458.

FrIEDRICH, L. Experimentelle Untersuchungen zur Analyse der zellulären Hitzeresistenz der Miesmuschel Mytilus edulis L. (In Vorbereitung)

KINNE, O., 1963. Adaptation, a primary mechanism of evolution. In: Phylogeny and evolution of crustacea. Ed. by H. B. Whittington \& W. D. I. Rolfe. (Spec. Publ. Mus. Comp. Zool, Cambridge, Mass. 27-50.)

- 1964. Non-genetic adaptation to temperature and salinity. Helgoländer weiss. Meeresunters. 9, 433-458.

LevirT, J., 1958. Frost, drought, and heat resistance. In: Protoplasmatologia. Handbuch der Protoplasmaforschung. Hrsg. von L. V. Heilbrunn \& F. Weber. 8 (6), 1-87.

Marsland, D. A., 1958. Cells at high pressure. Scient. Am. 199, 36-43.

Meryman, H. T., 1956. Mechanics of freezing in living cells and tissues. Science, N. Y. 124, 515-521.

PonAT, A. Experimentelle Untersuchungen zur zellulären Druckresistenz mariner wirbelloser Tiere. (In Vorbereitung)

Precht, H., 1964. Über die Resistenzadaptation wechselwarmer Tiere an extreme Temperaturen und ihre Ursachen. Helgoländer wiss. Meeresunters. 9, 392-411.

- \& Christophersen, J., 1965. Temperaturadaptation des Cilienepithels isolierter Kiemen und Fühlerspitzen von Mollusken. Z. wiss. Zool. 171, 197-209.

Prosser, C. L. (Ed,), 1958. Physiological adaptation. A symposium. Am. Physiol. Soc., Washington, 1-185.

ResнöFr, K., 1961. Untersuchungen zur zellulären osmotischen und thermischen Resistenz verschiedener Lamellibranchier der deutschen Küstengewässer. Kieler Meeresforsch. 17, 65-84.

SChlieper, C., 1960. Genotypische und phaenotypische Temperatur- und Salzgehalts-Adaptationen bei marinen Bodenevertebraten der Nord- und Ostsee. Kieler Meeresforsch. 16, 180-185.

- 1963. Biologische Wirkungen hoher Wasserdrucke. Experimentelle Tiefsee-Physiologie. Veröff. Inst. Meeresforsch. Bremerh. 8 (Sonderbd), 31-48.

- 1964. Cellular ecological adaptations and reactions demonstrated at surviving isolated gill tissues of bivalves. In: The cell and environmental temperature. Proc. of the Int. Symp. on Cytoecology, Leningrad 1963. Izd. 'Nauka' Moscow, 129-135 (in Russian).

- \& JÄckel, G.: Experimental investigations on the cellular heat resistance of the sea anemone Metridium senile. (Unpublished observations)

- \& Kowalskt, R., 1956. Ober den Einfluß des Mediums auf die thermische und osmotische Resistenz des Kiemengewebes der Miesmuschel Mytilus edulis L. Kieler Meeresforsch. 12, $37-45$.

- FLÜGEI, H. \& Rudolf, J., 1960. Temperature and salinity relationships in marine bottom invertebrates. Experientia 16, 470-474.

- Flügel, H. \& THeEde, H.: Comparative investigations on ecological cell physiology of marine temperate and tropical bottom invertebrates. Pbysiol. Zöol. (In print)

TheEde, H., 1965. Vergleichende experimentelle Untersuchungen über die zelluläre Gefrierresistenz mariner Muscheln. Kieler Meeresforsch. 21, 153-166.

Vernderg, F. J., SChlieper, C. \& SChNeIdER, D. E., 1963. The influence of temperature and salinity on ciliary activity of excised gill tissue of molluscs from North Carolina. Comp. Biochem. Pbysiol. 8, 271-285.

Usнakov, B., 1964. Thermostability of cells and proteins of poikilotherms and its significance in speciation. Physiol. Rev. 44, 518-560.

Zobeli, C. E. \& Morita, R. Y., 1956. Bacteria in the deep sea. In: The Galathea deep sea expedition, 1950-52. Ed. by A. F. Bruun, S. Greve, H. Mielche \& R. Spärck. Transl. from the Danish. Allen \& Unwin, London, 202-210. 


\section{Discussion following the paper by SCHLIEPER}

PRECHT: Im Anschluß an den Vortrag von Herrn Schlieper erscheint es angebracht, zu der von AleXANdrov (Q. Rev. Biol. 39, 35-77, 1964) vorgeschlagenen Unterscheidung von einem "hardening" (Schockanpassung) und einem "adjustment" (Resistenzadaptation in unserem Sinne) Stellung zu nehmen, da ein hardening auch bei Tieren vorkommen soll. Es handelt sich beim hardening um eine rasche, wahrscheinlich vorübergehende Resistenzzunahme, wenn Organismen extrem hohen Temperaturen ausgesetzt werden, während die Resistenzadaptation eine langsamer verlaufende, bleibende Anpassung an den ganzen Bereich der Adaptationstemperaturen darstellt. Im Gegensatz zum heat-hardening wissen wir über ein entsprechendes cold-hardening noch recht wenig; die von ALEXANDRov zitierte Frostabhärtung der Winterpflanzen ist sicherlich eine echte Kälteadaptation, also ein adjustment und kein hardening. Wenn die Resistenzänderung in den vorgetragenen Versuchen trotz veränderter Adaptationstemperatur nach einiger Zeit zurückgeht und sekundäre Ursachen wie Hungereffekte ausgeschlossen werden, so könnte man an ein hardening bei fehlender Resistenzadaptation denken. Wir versuchen zur Zeit, diese Probleme an Fischen zu klären, deren Resistenzadaptation so gut wie immer sinnvoll gegenüber beiden Extremtemperaturen verläuft.

KinNe: Es spricht manches dafür, daß die Geschwindigkeit, mit welcher eine bestimmte, nichtgenetische Adaptation erworben werden kann, eine Beziehung aufweist zur Geschwindigkeit, mit der sie wieder verlorengehen kann. Der Vorgang der De-Adaptation ist noch wenig erforscht. Untersuchungen von Merino (Blood 5, 1-31, 1950) ïber Erythrocytenabbau nach Rückkehr der Versuchspersonen von großen Höhen deuten darauf hin, daß De-Adaptationen aktive Prozesse sein können und nicht einfach einen passiven Verlust nach Aufhören des auslösenden Stressors darstellen müssen. Auf jeden Fall sind die meisten bisher untersuchten nicht-genetischen Adaptationen teilweise oder gänzlich reversibel. Ich bin mir daher im $Z$ weifel, ob eine klare Differenzierung zwischen hardening (,rasche, vorübergehende Resistenzzunahme ${ }^{\text {") }}$ und Resistenzadaptation ("langsamer verlaufende, bleibende Anpassung“) ohne weiteres möglich ist.

PRECHT (zu KINNE): Beim hardening dürfte es sich um eine schnelle Anpassung bei plötzlichen Temperaturänderungen handeln, die später abklingt, bei der Resistenzadaptation um eine langsame Anpassung an relativ konstante Temperaturen. Die von Herrn SCHLIEper gebrauchten Ausdrücke spezifisch und unspezifisch sind deshalb für eine Unterscheidung beider Phänomene wenig geeignet, weil zum Beispiel das von AleXandrov an pflanzlichen Zellen untersuchte heat-hardening zwar im Hinblick auf manche schädigenden Faktoren (Alkohol, Essigsäure, hohe Drucke etc.) unspezifisch ist, nicht jedoch gegenüber der hier besonders interessierenden anderen Extremtemperatur. Die Resistenzadaptation der Fische ist gerade im Hinblick auf die beiden Extremtemperaturen spezifisch, doch zeigen warmadaptierte Tiere oft eine unspezifische Resistenz gegenüber vielen anderen Faktoren. Die Frostabhärtung der Winterpflanzen ist in typischer Weise unspezifisch. Wir haben wegen dieser Schwierigkeiten die Ausdrücke sinnvoll (reasonable) und paradox verwendet, ohne daß damit eine teleologische Bedeutung verknüpft werden soll.

KINNE: Ich mödhte einen Deutungsversuch der Schlieperschen Versuchsergebnisse zur Diskussion stellen. Herr SCHLIEPER hat Versuchstiere, welche vorher längere Zeit bei völlig konstanten Wassertemperaturen gehalten worden waren, plötzlich in andere Temperaturstufen ïberführt. Obgleich die neuen Temperaturstufen durchaus im Normalbereich der Versuchstiere lagen, hat möglicherweise die V e r änd e rung der Wassertemperatur als solche einen Stress dargestellt, der entsprechende „adjustments" verursachte; später wurde die neue Situation dann nicht mehr als Stress „empfunden" und die adjustments (Resistenzveränderungen) gingen mangels erneuter "re-inforcements" wieder verloren.

SchliePer: Ich möchte dem Deutungsversuch yon Herrn KrnNe voll zustimmen. Unsere Versuchstiere, die plötzlich in die Wärme gebracht worden sind, haben zunächst ihre zelluläre Hitzeresistenz erhöht. Da sie aber noch in ihrem artspezifischen Temperaturbereich verblieben, bauten sie anschließend die "vorsorglich" erhöhte Hitzeresistenz wieder ab. Bei der Unter- 
suchung der Höhenanpassung des Menschen sind meines Wissens ähnliche Beobachtungen gemacht worden. Kommen Tieflandbewohner plötzlich in größere Höhen, so steigt zunächst der Hämoglobingehalt ihres Blutes in Anpassung an die niedrigere Sauerstoffspannung. Bei längerem Höhenaufenthalt wird die anfängliche Steigerung des Hämoglobingehaltes aber wieder abgebaut. - Eíne zweite Deutungsmöglichkeit böte die Annahme eines gleichzeitigen Wirksamwerdens der experimentell verursachten adaptiven Resistenzänderung und einer entgegengesetzten jahreszeitlichen Resistenzverschiebung, die im Zusammenhang mit dem Reproduktionszyklus steht. Die anfängliche umgebungsbedingte Resistenzänderung würde in diesem Falle durch eine endogenbedingte Resistenzverschiebung wieder rückgängig gemacht. $-\mathrm{Zu}$ den vorangegangenen Diskussionsbeiträgen möchte ich noch bemerken, daß nach unseren Erfahrungen das gesamte Resistenzpotential einer Zelle durch plötzlichen Hitzeschock beeinflußt werden kann. Zwischen diesem schnellen heat-hardening und der langsameren heat-adaptation gibt es aber meines Erachtens gleitende Übergänge.

Precht: Das ist auch bei Pflanzen der Fall.

BRück: Wir beschäftigen uns mit der Adaptation von Warmblitern, insbesondere mit der Kälteadaptation; dabei ergibt sich immer wieder die Frage, ob bestimmte beobachtete Modifikationen als stressorspezifisch oder stressorunspezifisch aufzufassen sind. Ich möchte deshalb fragen, ob die Resistenzsteigerung gegen Kälte und Wärme beim Kaltblüter nur als unspezifisches Phänomen (hardening) vorkommt, oder ob es auch eine "gezielte" (stressorspezifische) Steigerung der Kälte- und Hitzeresistenz gibt?

Precht (zu BRÜCK): Fische zeigen ganz allgemein eine sinnvolle Anpassung an extrem tiefe und hohe Temperaturen. Oft sind warmadaptierte Fische durch eine allgemeine Resistenz ausgezeichnet (z. B. gegenüber $\mathrm{CO}_{2}$, Gifte, Sauerstoffmangel, Narkotika; vgl. E. v. BudoenBROCK, Z. wiss. Zool. 164, 173, 1960). Thre Kälteresistenz ist jedoch herabgesetzt. Diese ist wiederum bei den kaltadaptierten Tieren erhöht, was somit als eine "gezielte" Anpassung gewertet werden könnte, doch mag es andere, noch unbekannte Faktoren geben, die mit der Kälteresistenz parallel verlaufen. Man darf die Probleme der allgemeinen Resistenz aber nicht zu sehr schematisieren; gerade die Untersuchungen von Herrn Schlieper an Muschelkiemen haben dies gezeigt. Bei Arten aus kälteren Gebieten ist der tolerierte Salzgehaltsbereich größer bei kaltadaptierten Tieren, bei solchen aus wärmeren Gebieten dagegen ausgedehnter bei warmangepaßten Individuen.

SCHARF: Die Untersuchungen der russischen Autoren an isoliertem Warmblütergewebe in vitro sind mit Sicherheit nicht auf das Ganztier übertragbar. Temperaturanpassung ist bei Vögeln und Säugern ohne $Z$ weifel möglich, doch handelt es sich um ein vieldimensionales Geschehen, das zum Teil nervös, zum Teil hormonal gesteuert wird und wahrscheinlich zu einem Teil auch noch auf einem dritten Niveau (Direktwirkung mancher im Blute kreisender Substanzen nichthormonaler Art auf Leber und Nieren). In der Gewebekultur ist alles ganz anders. Zumindest gilt das Temperaturintervall, das für isolierte Gewebe ermittelt wurde, überhaupt nicht für das Ganztier, das viel empfindlicher reagiert.

Schlieper: Nach unseren Befunden besteht bei vielen marinen Evertebraten eine deutliche Relation zwischen der Resistenz der ganzen Individuen und der ihrer isolierten Gewebe.

ROBERTS: Aside from examples which almost certainly are ones illustrative of thermal resistance adaptations such as those cited by Schlteper today and earlier by UsHakov (Physiol. Rev. 44, 518-560, 1964), I think that UsHakov's view is sound - that some thermostability findings, apparently cases of resistance adaptation, might be the result of secondary responses related to significant capacity adaptations. This is implicit, I feel, in the results of Bascow \& Nigrelli (Zoologica, N. Y., 49, 41-51, 1964) which suggest that although the activity (or concentration?) of brain cholinesterases prepared from the fish Fundulus seem to show resistance adaptations, in reality, the observed activity changes more likely represent capacity adaptations of a thermal-homeostatic sort.

SCHLIEPER: Ich möchte aber darauf hinweisen, daß nach UsHakov Verschiebungen in der zellulären Hitzestabilität bei Poikilothermen in der Regel ("ustally") nicht in direkter Be- 
ziehung zu Anderungen in der Umgebungstemperatur stehen sollen. Demgegenüber beweisen unsere Beobachtungen, daß bei euryöken marinen Evertebraten auch zelluläre nichtgenetische (umgebungsbedingte) Resistenzadaptationen vorkommen.

PRECHT: Soweit ich Ushakov verstanden habe, stellt er eine Resistenzadaptation der Gewebe - wie sie viele von uns gefunden haben - bei adulten Tieren deshalb in Frage, weil die Zellen zumeist resistenter sind als das ganze Tier. Eine Resistenzadaptation könnte sich durch Selektion dann gar nicht herausbilden, weil sie bei Temperaturen auftritt, bei denen das intakte Tier längst tot ist. Aber die von vielen Autoren gefundene Resistenzadaptation auf dem Zellniveau könnte ja auch einfach ein Nebenprodukt sein.

ChrISTOPHERSEN: Eine Resistenzadaptation kann man bereits an isolierten Enzymproteinen beobachten. Bewahrt man deren Lösungen bei unterschiedlichen Adaptationstemperaturen auf, so kann man (etwa bei Pankreatin, Invertase oder Alkoholdehydrogenase) eine entsprechend veränderte Stabilität Inaktivierungstemperaturen gegenüber beobachten. Über die beteiligten Mechanismen der temperaturbedingten Strukturfestigungen ist noch wenig bekannt. Wir nehmen an, daß sie im Bereich der $z$ wischenmolekularen Bindungen ( $\mathrm{H}-\mathrm{Briidken}$ ) zu suchen sind.

KINNE: Ich möchte versuchen, die Diskussion wieder etwas mehr auf das von Herrn SchliEPER in seinem Vortrag behandelte Thema zurückzuführen. Für uns Meeresbiologen sind die durch unterschiedliche Temperatur- und Druckeinwirkungen verursachten. Verschiebungen der oberen und unteren Grenztemperaturen verschiedener Lebensprozesse von außerordentlicher Wichtigkeit. Herr SCHLIEPER hat festgestellt, daß litorale Flachwasserformen vielfach eine erstaunlich hohe Druckresistenz besitzen. Die betroffenen Arten wären also auf Grund ihrer physiologischen Potenz durchaus in der Lage, größere Tiefen zu besiedeln. Vermuten Sie hier als Ursache der Beschränkung auf das Litoral primär Konkurrenzphänomene oder historische Gegebenheiten?

SCHLIEPER: Ich nehme an, daß die untersuchten litoralen Arten deshalb nicht in die Tiefsee vorrücken können, weil ihnen andere Eigenschaften fehlen, welche sie in der Tiefe benötigen.

KnNE: Sie haben ferner ermittelt, daß die zelluläre Druckresistenz bei supranormalen Temperaturen (in der Wärme) größer ist als bei subnormalen Temperaturen (in der Kälte). Können Sie für diese Korrelationen eine Erklärungsmöglichkeit anbieten?

Schlieper: Die zelluläre Druckresistenz isolierter Kiemenstücke der Miesmuschel ist in der Wärme deutlich größer als in der Kälte. Dieser Befund stimmt mit früheren Beobachtungen von Marsland (Scient. Am., 199, 36-43, 1958) und anderen ïberein, nach denen bei höherer Temperatur ein größerer Druck angewandt werden muß, um die Kriechbewegungen der Amöbe in gleichem Maße zu hemmen. Nach MarsLand wird durch die bei hohem Druck bewirkte Kompression des Protoplasmas mehr festes Gel, mit dem die Amöbe allein Bewegungen ausführen kann, in dünnflüssigeres Sol überführt. Zunehmende Temperatur hat jedoch den entgegengesetzten Effekt. Bei Erwärmung verschiebt sich die Gel-Sol-Reaktion in der Richtung der Gel-Bildung. Kiemenstücke von warmangepaßten Muscheln überleben dementsprechend bei hohem Druck in der Kälte schlechter. Passe ich jedoch die Versuchstiere vor dem Druckexperiment längere Zeit an niedrigere Temperatur an, so überleben ihre Gewebe bei hohem Druck in der Kälte relativ besser, wenn sie auch nicht den hohen Resistenzgrad der in der Wärme untersuchten Gewebestücke erreichen.

BRücK: Sie haben Beispiele für positive gekreuzte Adaptation (Kälteadaptation erhöht Druckresistenz) gebracht. Es würde midh sehr interessieren, ob Sie auch eine rein stressorspezifische Adaptation in Threm Versuchsmaterial nachweisen konnten.

SCHLIEERR: Wir haben nur genetische (artspezifische) zelluläre Drudkresistenzen experimentell gemessen. Bisher war es aus technischen Gründen unmöglich, nichtgenetische Druckanpassungen zu untersuchen. $\mathrm{Ich} z$ weifele aber nicht, daß dieses möglich sein wird, wenn wir erst marine Evertebraten längere Zeit in strömendem Meerwasser bei höheren Drücken halten können. 